\title{
NOTES
}

\section{THE CLAYTON ACT'S NEW SECTION 7: A STORM WARNING FOR THE MERGER PARADE*}

To cope with monopolies and restraints of trade in their incipiency, Congress passed the Clayton Act ${ }^{1}$ condemning specific practices regarded as potentially: dangerous to competition. ${ }^{2}$ Section 7 prohibited acquisitions of stock by one corporation in another where the effect "may be to substantially lessen competition" between the two corporations, or "tend to create a monopoly."3 However, the section was emasculated by an unsympathetic judiciary." While verbally recognizing the legislated standard of reasonable probalility of harm to competition, courts actually required proof of certainty of harm."

*Hamilton Watch Co. v. Benrus Watch Co., 114 F. Supp. 307 (D. Conn.), afj'd, 200 F2d 738 (2d Cir. 1953).

1. 38 STAT. 730 (1914), 15 U.S.C. $\$ \$ 12-27,44$, 18 U.S.C. $\$ 412,2 \$$ U.S.C. $\$ \$ 381-3$, 386-90a, 29 U.S.C. $\$ \$ 53-1$ (1946).

2. "Broadly stated the bill, in its treatment of unlawful restraints and monupolics, seeks to prohibit and make unlawful certain trade practices which, as a rule, singly and in themselves, are not covered by the act of July 2, 1890 [Sherman Act], or othrr existing antitrust acts, and thus, by making these practices illegal, to arrest the creation of trust $\varsigma_{\text {, }}$ conspiracies, and monopolies in their incipiency and before consummation." SE::. Fex. No. $698,63 \mathrm{~d}$ Cong., $2 \mathrm{~d}$ Sess. 1 (1914). For cases recognizing this purpose sce Standard Fashion Co. v. MIagrane-Houston Co., 258 U.S. 346, 355-7 (1922); Standard Oil Co. v. FTC, 282 Fed. S1 (3d Cir. 1922), aff'd sub stom. FTC v. Sinclair Refining Co., 261 U.S. 463 (1923).

3. The section read in part as follows: "[N]o corporation engaged in commerce shall acquire, directly or indirectly, the whole or any part of the stock or other share capital of another corporation engaged also in commerce where the effect of sueh acquisi= tion may be to substantially lessen competition between the corporation whose stcels is so acquired and the corporation making the acquisition, or to restrain such commarce in any section or community, or tend to create a monopoly of any line of commerce." 38 STAT. 730, 731-2 (1914). A similar provision dealt with purchases of stock by holding companies. And all purchases made solely for investment were specifically esenpted from the section. Id. at 732 .

There is some dispute as to Congress' purpose in enacting this section. Compore Note, Section 7 of The Clayton Act: A Legislative History, 52 CoL L. Rev. 766,769 (1952), with H.R. Rep. No. 1191, S1st Cong., 1st Sess. 3-4 (1949).

4. See Comment, 57 YaLE L.J. 613 (194S).

During the Senate debate which led to the adoption of the 1950 amcndment, Senator O'Conor, floor leader of the amendment, referred to the original $\$ 7$ as a "nullity" and a "mockery of the ... law." 96 Conc. Rec 16506 (1950). See also 95 Co:zc. Rec 11498, 11503 (1949).

5. This is the Sherman Act's standard of legality for intercorporate stoclsholding and mergers. United States v. Columbia Steel Co., 334 U.S. 495 (1948); Unitcd States v. U.S. Steel Corp., 251 U.S. 417 (1920); United States v. United Shoe Meachinery Co., 247 U.S. 32 (1918); United States v. American Tobacco Co., 221 U.S. 106, 179 (1911); United States v. Standard Oil Co., 47 F.2d 2 SS (E.D. A1o. 1931). It was 
And exceptions to the section were interpreted in a manner which prevented effective enforcement of the underlying legislative policy. ${ }^{6}$

In 1950, Congress amended Section $7^{7}$ to restore its effectiveness in the struggle to maintain a competitive economy. ${ }^{8}$ The section was extended to cover acquisitions of corporate assets. And legislative history discloses a clear intent to reassert potentiality of harm to competition as the test of legality under the amended section. ${ }^{0}$ However, verbal similarities between the old and new sections ${ }^{10}$ have led to conflicting interpretations ${ }^{11}$ of the

read into the Clayton Act by the Third Circuit in Standard Oil Co. v. FTC, 282 Fed. \&1 (3d Cir. 1922), aff'd sub nom. FTC v. Sinclair Refining Co., 261 U.S. 463 (1923) ( 33 decision). This was approved by the Supreme Court in International Shoe Co. v. FTC, 280 U.S. 291, 298 (1930) ( $\$ 7$ decision). For a classic example of the application of the Sherman Act standard to a $\S 7$ proceeding, see United States v. Republic Sted Corp., 11 F. Supp. 117 (N.D. Ohio 1935).

6. Judicial handling of the asset loophole was typical. The original section did not specifically refer to acquisitions of assets. Thus while company $A$ might not be able to buy the stock of company $B$ where the result might be to substantially lessen competition, company $A$ could purchase all the assets of company $B$ without violating $\$ 7$. United States v. Celanese Corp., 91 F. Supp. 14 (S.D.N.Y. 1950). The courts widencd this loophole by holding that the section could not be used to prevent the use of illugal stock acquisitions as an intermediate device in acquiring the assets of a competitor. $\mathrm{F}$ TC v. Western Meat Co., 272 U.S. 554, 561 (1926). And in Arrow-Hart \& Hegeman Electric Co. v. FTC, 291 U.S. 587 (1934), the Supreme Court held that where the defendant used its stock control to acquire the physical assets of a competitor, the FTC could not order divestiture of the assets although the stock was admittedly purcliased in violation of $\S 7$, and the Commission had begun proceedings against the stock purchases prior to the acquisition of assets.

7. 64 Stat. 1125 (1950), 15 U.S.C. \& 18 (Supp. 1952). The amendment is often referred to as the Celler Anti-Merger Act.

8. H.R. Rep. No. 1191, 81 Cong., 1st Sess. (1949) passim; SEN. Rep. No. 1775, 81st Cong., 2d Sess. (1950) passim.

9. See, e.g., id. at 4-5: "[I]t is the purpose of this legislation to assure a broador construction of the more fundamental provisions that are retained than has been given in the past. The conmittee wish to make it clear that the bill is not intended to revert to the Sherman Act test. The intent here, as in other parts of the Clayton Act, is to cope with monopolistic tendencies in their incipiency and well before they have attaincd such effects as would justify a Sherman Act proceeding." (emphasis supplied). Similar statements were made by the House Judiciary Committee. H.R. REP. No. 1191, 81st Cong., 1st Sess. 8 (1949).

These statements are particularly significant in view of testimony by the Gencral Counsel of the FTC urging Congress to specify its intent to establish a stricter standard of legality than the courts had read into the old section. Hearings beforc Scnale Sul committee of the Committee on the Judiciary on H.R. 2734, 81st Cong., 1st \& 2d Sess. 24-6 (1949-50).

10. The amended section prohibits intercorporate stock or asset acquisitions "where in any line of commerce in any section of the country, the effect may be stubstantially to lessen competition, or to tend to create a monopoly." 64 STAT. 1125-6 (1950), 15 U.S.C. $\$ 18$ (Supp. 1952). Compare the original section quoted supra note 3.

The vagueness of the new standard was emphasized by Senator Donnell in his minority report on the bill. Sen. Rep. No. 1775, 81st Cong., 2d Sess. 19-23 (1950).

11. See e.g., Neal, The Clayton Act and the Transamerica Case, 5 Stan. L. Rev. 
new test. Therefore, judicial construction of the amendment has been eagerly awaited.12

In Hamilton Watch Co. v. Benrus II'atch Co. ${ }^{13}$ the amended section was construed for the first time. ${ }^{14}$ Early in 1952 Benrus began making heary purchases of Hamilton stock. When Hamilton learned of this, its officers, directors, and major stockholders formed a voting trust which accumulated sufficient common stock to insure working control of the corporation. Meanwhile, Benrus purchased enough stock to guarantee, through cumulative

179, 187-90, 229-30 (1953); Comment, Amendment to $\$ 7$ of the Cloyton Act, 46 IrL. L. Rev. 444, $453-4$ (1951) ; Note, Section 7 Of The Clayton Act: A Legislatie History, 52 CoL. L. Rev. 766, 776-7 (1952) ; Note, 64 H.iRv. L. Rev. 1212-4 (1951).

12. The importance of the amendment to businessmen can hardly be overestimated in the light of the great number of mergers which have occurred since its pascage, and which are planned for the near future. See, c.g., Company Mifrgcrs: How, Ihy, Business Week, Mar. 7, 1953, p. 29; Trying To Figure Where The Shoe Industry Is Going, id., July 25, 1953, p. 138; ITerger Mechanics: You Hare To Try Them To KnGa If Theyll Work, id., Aug. 8, 1953, p. 95; Earthmozing: Eacryone Gets In The Act, id., Aug. 15, 1953, p. 56; Industrial Truck Makers Get Merger Fecer, id., Sept. 26, 1953, p. 110.

The amendment is of equal importance to those alarmed at the high and increasing concentration of economic power in our society. Although there is some dispute among economists as to the contribution of mergers to this phenomenon, compare Burrens, Lintaner \& Cary, Corforate Mergers c. 9 (1951), zith Fedmul Trade Consussion, The Merger Movenent: A Summary Report (1948), there can be no doubt that Congress thought it was dealing with this problem when it passed the ameniment. See, e.g., H.R. REP. No. 1191, S1st Cong., 1st Sess. 3 (1949): "Such in general outline is the broad economic problem of high and increasing [economic] concentration with which this legislation is concerned."

13. 114 F. Supp. 307 (D. Conn.), aff'd, 206 F.2d 738 (2d Cir. 1953).

14. The first case arising under the amended section was Fargo Glass \& Paint Co. v. Globe American Corp., 201 F.2d 534 (7th Cir. 1953), recersing 101 F. Supp. 400 (X.D. I11. 1951). The Seventh Circuit, without any discussion of the meaning of the amendsd section, held that it had not been violated since the company involved manuiactured lses than 2 percent of the relevant product in an industry in which the 10 leading manufacturers manufactured approximately 52 percent of the national total. The dicision actually turned on the definition of the relevant product. Comfore the trial court upinion on this point, 101 F. Supp. at 461-5, with that of the Court of Appeals, 201 F.2d at 537-8.

The only complaint the FTC has issued under the amended section is against Pillsbury Mills, Inc., for buying up Ballard \& Ballard, a Louisville milling company, and Duff's Baking Mix Division of American Home Products Corp. The hearing examiner dismissed the complaint without prejudice on two grounds: a) the industry statisties were unreliable and $b$ ) even if they were reliable, the evidence produced by the FTC counsel in support of the complaint was insufficient to raise a prima facie case of violation. Initial Decision, Pillsbury Mfills, Inc, FTC Dkt. 6000 (April 22, 1953). Although the decision may be supported on the first ground mentioned above, but see Edwards, The Effects of Mergers Upon Competition in Minhemng: Currenr Pronless a:id Tnbonres 48, 49-50 (1952), the second ground seems clearly invalid. Counsel in support of the complaint not only met the test suggested p. $240 \mathrm{infra}$, but also made a rule of reason type analysis of the factors relevant to the effectiveness of competition within the relevant industries. Brief for Appellant, pp. 45-58, 59-61, Pillsbury Alills, Inc, FTC Dlt. 6000 (April 22, 1953). The hearing examiner's order is now on appeal within the Cummission. 
voting, minority representation on Hamilton's board of directors. To prevent Benrus from voting its stock, Hamilton brought suit claiming that Benrus' purchases violated Section 7 of the Clayton Act. Judge Hincks granted a preliminary injunction on the ground that minority representation of Benrus on Hamilton's board of directors would create just such a threat to competition as the amended section was designed to prohibit. ${ }^{15}$ The Second Circuit affirmed. ${ }^{16}$

Benrus argued that its stock purchases were specifically sanctioned by a provision, retained in the 1950 amendment, exempting stock purchases made solely for investment. ${ }^{17}$ In a leading pre-amendment decision, the Third Circuit held that this exception applied to a case in which one railroad had acquired one-half of the stock in a competing road, and one-third of the stock in another, and had elected several of its employees to their boards of directors. The court stated that without an actual substantial lessening of competition or an actual intent to bring this about, the stock purchases were made solely for investment within the meaning of the Act. ${ }^{18}$ Such reasoning seems clenrly to have ignored the object of the Clayton Act. To require proof of actual harm to competition is incompatible with Congressional efforts to supplement the Sherman Act by reaching restraints of trade in their incipiency and before consummation. ${ }^{10}$ The primary consideration should be the probability of harm to competition. ${ }^{20}$ And the intent of the acquiring firm is relevant only as one factor affecting that probability. Stock purchases made solely for investment purposes were exempted from the original Section 7 because Congress felt that such purchases could not raise an inference of a reasonable probability of harm to competition. ${ }^{21}$ Courts should not extend the exemption

15. Hamilton Watch Co. v. Benrus Watch Co., 114 F. Supp. 307, 316-17 (D. Conn. 1953). Judge Hincks also held that acquisition of a competitor's stock violates the amended section when the acquisitions are made pursuant to a plan to obtain control, the success of which at the time of the acquisition was likely, and which if successful would probably result in a substantial lessening of competition. He found all these elements present in the instant case and held that they were an alternative ground for granting the preliminary injunction. Id. at 316 .

16. Hamilton Watch Co. v. Benrus Watch Co., 206 F.2d 738 (2d Cir. 1953).

17. "This section shall not apply to corporations purchasing such stock solely for investment and not using the same by voting or otherwise to bring about, or in attempting to bring about, the substantial lessening of competition." 64 STAT. 1126 (1950), 15 U.S.C. $\S 18$ (Supp. 1952).

18. Pennsylvania R.R. v. ICC, 66 F.2d 37, 40 (3d Cir. 1933), aff'd without opinion by an equally divided court, 291 U.S. 651 (1934). Cf. Temple Anthracite Coal Co. v. FTC, 51 F.2d 656, 661 (3d Cir. 1931).

19. Sec Sen. Rep. No. 1175, 81st Cong., 2d Sess. 6 (1950).

20. See note 2 supra.

21. See H.R. Rep. No. 627, 63d Cong., 2d Sess. 17 (1914). Stock purchases made solely for investment, but whose inherent tendency is to lessen competition to a substantial degree, can be attacked under the Sherman Act. Cf. Shotkin v. General Electric Co., 171 F.2d 236, 238 (10th Cir. 1948). 
to purchases made only partially for investment purposes when such a probability results. ${ }^{22}$ In Benrus Judge Hincks apparently adopted this line of reasoning. The court found that Benrus' purchases were an investment hedge against the possible loss of Swiss imports. ${ }^{23}$ But control of Hamilton was also an objective of those purchases ${ }^{24}$ and the court therefore held the exception inapplicable. On this point Benrus clearly recognizes that the test of legality under amended Section 7 is potentiality of harm to competition.

The court's emphasis on potentiality of harm to competition is seen even more clearly in its holding that minority representation of Benrus on Hamilton's board of directors would violate Section 7 . In a recent case brought under the original section the Third Circuit held, following pre-amendment decisions on this point, ${ }^{25}$ that "the mere showing of common ownership [of ten competing banks] will not support an inferential finding that competition

22. It is not necessary to overrule the Pemsyliaxia R.R. case to reach this conclusion. That case may be distinguished on the ground that the court found that the purchases were made solely for investment because the "evidence shows that railrosd companies generally invest a substantial part of their surplus in securities of companies constituting members of the family group which male up the system of the purchasing company. This was the custom both before and after the passage of the Clayton Act. ..." Pennsylvania R.R. v. ICC, 66 F.2d 37, 40 (3d Cir. 1933), aff'd without opinion by as: equally dizided court, 291 U.S. 651 (1934). Furthermore, the case was decided during the depression and the court must have been influenced by the the fact that "to force all this stock suddenly upon the market might have such a disastrous effect in these trüublous times. ..." Ibid.

23. Benrus has no domestic watch movement facilities; it imports its movements from its plant in Switzerland. Hamilton's entire plant is domestic. There is now-and there has been since last year- a strong movement to raise the tariffs on importcd movements. There is also the danger that war might break out and cut of Benrus' imports from Switzerland. If either event should occur, the value of Hamilton's stocl: would increase tremendously since its main competitors (four of the Bix Six wateh companies who depend on Swiss imports) would lose a substantial part of their market to Hamilton. Benrus' stock purchases in Hamilton were thus to some extent an investment hedge against a rise in tariffs or an outbreak of hostilities. Hamilton Watch Co. v. Benrus Watch Co., 114 F. Supp. 307, 313 (D. Conn. 1953).

24. Judge Hincks' finding was based mainly on the following considentions: Benrus spent over $\$ 1,300,000$ for the Hamilton stock, much of which appears to have been borrowed. It had often paid premium prices for the stock while a pure investment policy would have been pursued with more patience. It sold, at a loss, a sizcable investment in Elgin (another domestic producer) during the period it vas buying the Hamilton stock; yet during this period Elgin's business was booming while Hamilton was runing at a loss and had passed its first dividend since the beginning of World War II. Benrus ceased purchasing Hamilton stock once it became apparent that the voting trust, at least for the time being, had consolidated control of Hamilton. In addition, Benrus plainly evidenced its hostility to the voting trust from the time of its organization and at one time offered to refrain from voting Benrus stock for one year if the trust were dissolved. Id. at $313,316$.

25. Pennsylvania R.R. v. ICC, 66 F.2d 37, 3S-9 (3d Cir. 1933), aff'd zwithout opision by an equally divided court, 291 U.S. 651 (1934); Temple Anthracite Coal Co. v. FTC, 51 F.2d 656, 661 (3d Cir. 1931). 
between them ... may be lessened."26 But, in Benrus, Judge Hincks declared that mere minority representation on a competitor's board of directors would violate Section 7 "because of the opportunity thereby afforded to persuade or compel a relaxation of the full vigor" of the latter's competitive activity. ${ }^{27}$

The major unsolved problem under the amended section is the plaintiff's burden of proof. ${ }^{28}$ The pre-amendment cases did recognize that reasonable probability of harm to competition was the Clayton Act test of legality.90 But the courts refused to find a reasonable probability of harm to competition, unless the defendant's actions violated the Sherman Act's rule of reason. ${ }^{30}$ They obliterated the difference between the Sherman and Clayton Act stanclards of legality by imposing a similar burden of proof on the plaintiff regardless of the difference in the verbal standards which the statutes apparently embodied. $^{31}$ Yet if the Clayton Act's policy is to be made effective, the burden of proof on the plaintiff must be lighter in a Clayton Act proceeding than in a Sherman Act proceeding. The Supreme Court has said, referring to Section 3, that the Clayton Act's specific statutory prohibitions represent in clearly defined public policy which dispenses with the necessity of difficult standards of economic proof. ${ }^{32}$ Thus, in the Standard Stations case the Court held that a reasonable probability of substantial harm to competition would be

26. Transamerica Corp. v. Board of Governors of the Federal Reserve System, 206 F.2d 163, 168 (3d Cir. 1953).

27. Hamilton Watch Co. v. Benrus Watch Co., 114 F. Supp. 307, 317 (D. Cont1. 1953) (emphasis supplied).

28. Commentators agree on the interpretation to be given other elements of the amendment. For conflicting conclusions on the burden of proof isste see authorities cited note 11 supra.

29. E.g., Standard Fashion Co. v. Magrane-Houston Co., 258 U.S. 346, 357 (1922) ; International Shoe Co. v. FTC, 280 U.S. 291, 298 (1930) ; Pennsylvania R.R. v. ICC, 66 F.2d 37, 38-9 (3d Cir. 1933), aff'd without opinion by an equally divided court, 291 U.S. 651 (1934) ; Standard Oil Co. v. FTC, 282 Fed. 81, 86-7 (3d Cir. 1922), aff'd sılb nonn. FTC v. Sinclair Refining Co., 261 U.S. 463 (1923).

30. "[I]n determining whether given acts ... substantially lessen competition and tend to create a monopoly within the meaning of the Clayton Act, the only standard of legality with which we are acquainted is the standard established ... by the courts in construing the Sherman Act. ..." Standard Oil Co. v. FTC, 282 Fed. 81, 86-7 (3d Cir. 1922), aff'd sub nom. FTC v. Sinclair Refining Co., 261 U.S. 463 (1923). Sce also note 5 supra.

31. See Schwartz, Potential Impairment of Competition-The Impact of Standard Oil of Cal. v. United States on the Standard Of Legality under the Clayton Act, $98 \mathrm{U}$. of PA. L. Rev. 10, 33 (1949).

32. See, e.g., the Supreme Court's recent discussion of this point in Times-Picayunc Pub. Co. v. United States, 345 U.S. 594 (1953). "While the Clayton Act's more specifrc standards illuminate the public policy which the Sherman Act was designed to subserve ... the Government here must measure up to the more stringent law. . . " Id. at 609-10. "To be sure, economic statistics are easily susceptible to legerdemain, and only the organized context of all relevant factors can validly translate raw data into logical cause and effect. But we must take the record as we find it, and hack through the jungle as best we can ... [because] this suit was not brought to adjudicate a trade practice 
inferred automatically from proof that the challenged exclusive dealer contracts affected a substantial share of the relevant line of commerce. ${ }^{33}$ The main difficulty with this quantitative substantiality doctrine is that the practice inrolved may actually increase rather than decrease the vigor of competition. ${ }^{34}$ Therefore, the use of an irrebuttable presumption of illegality, on a showing that a substantial share of the relevant line of commerce is affected, will occasionally decrease the effectiveness of competition in the relevant market.

The Section 7 standard of legality should combine the judicial insights embodied in the Sherman Act rule of reason and the doctrine of quantitative substantiality. The scope of the inquiry in a Section 7 case should be similar to that undertaken in cases involving Sherman Act violations: all the elements

.. . banned by specific statutory prohibitions ahich by a clcarly defincd public policy dispense with difficult standards of economic proof." Id. at 621-2 (emphasis supplied).

In the modern leading case on $\$ 3$, the Court vent to great lengths to cainlain its decision on the plaintiff's burden of proof. "To interpret that section as requiring proof that competition has actually diminished would make its very explicitness a msans of conferring immunity upon the practices which it singles out. . . . It seems hardly likely that having with one hand set up an express prohibition against a practice thought to be beyond the reach of the Sherman Act, Congress meant, with the othcr hand, to reestablish the necessity of meeting the same tests of detriment to the public interest as that Act had been interpreted as requiring. . . . To insist upon such an investigation would be to stultify the force of Congress' declaration that requirements contracts are to be prolinbited whenever their cffect "may be' to substantially lessen competition." Standard Oil Co. v. United States, 337 U.S. 293, 311-13 (1949) (emphasis supplied).

This argument certainly applies with equal force to $\S 7$ which prohibits intercorporate stockholding and mergers whonzer their effect may be to lessen complition substantially. And the Supreme Court has already recugnized that the standard of legality under $\$ 7$ should be similar to the standard of $\$ 3$. It was in a $\$ 3$ case that the Sherman Act's rule of reason was first read into the Clayton Act. Standard Oil Co. v. FTC, 282 Fed S1 (3d Cir. 1922), aff'd sub nom. FTC v. Sinclair Refining Co., 261 U.S. 463 (1923). And the Court cited $\$ 3$ cases as precedent when it read that rule into $\$ 7$. International Shoe Co. v. FTC, 280 U.S. 291,298 (1930). It vould thus be particularly appropriate for the Court to use the standard it has recently established under $\$ 3$ as a guide to the standard it should establish under $\$ 7$.

33. Standard Oil Co. v. United States, 337 U.S. 293, 317 (1949): "We cunclude, therefore, that the qualifying clause [may be to substantially lessen competition] of $\$ 3$ is satisfied by proof that competition has been foreclosed in a substantial share of the line of commerce affected. ..." See also United States v. Richfield Oil Corp., 99 F. Supg. 230, 286 (S.D. Cal. 1951), aff'd per currian, 343 U.S. 922 (1952). This quantitative substantiality test of $\$ 3$ was recently approved in Times-Picayune Pub. Co. v. United States, 345 U.S. 594, 608-09 (1953): "Where the seller enjoys a monopolistic position in the market for the 'tying' product, or if a substantial volume of commerce in the 'ticd' product is restrained, a tying arrangement violates the narrower standards expressed in $\$ 3$ of the Clayton Act because from either factor the requisite potential lessening of competition is inferred." (court's emphasis).

34. See Lockhart \& Sacks, Relezance of Economic Factors is Detcrmining actitilacr Exclusive Arrangements Violate Section 3 of the Clayton Act, 65 HLan. L. Rex. 913 (1952). 
affecting competition should be examined in order to determine whether the particular intercorporate stockholding or merger creates a reasonable probability of harm to what economists refer to as the "workability" or "effectiveness" of competition within the relevant industry. ${ }^{35}$ But no one can say with certainty what will produce "workable" or "effective" competition. ${ }^{30}$ It is generally agreed, however, that the effectiveness of competition usually varies directly with the number of sellers in the market. ${ }^{37}$ Thus once the plaintiff has shown that a merger affects a substantial share of the relevant market, the risk of non-persuasion should be placed on the defendant to prove that in the particular industry involved the significant reduction in the number of sellers will not decrease the effectiveness of competition. ${ }^{38}$

35. Such an inquiry is called for in order to avoid prohibiting those intercorporatc stockholdings and mergers which increase rather than decrease the workability of competition. Cf. Hefleblower, Economics of Size, 24 J. of Business of U. of Cni. 253, 259-60, 265-8 (1951) ; Sunderland, Changing Legal Concepts, 24 id. at 235, 249-52; Adelman, Business Size \& Public Policy, 24 id. at 269, 277-9; Edwards, supra note 14, at 52. It is also called for by clearly expressed Congressional intent. "It is expected that, in the administration of the act, full consideration will be given to all matters bearing upon the maintenance of competition, including the circumstances giving rise to the acquisition." SEN. REP. No. 1775, 81st Cong., 2d Sess. 7 (1950).

Such an inquiry is to be expected in proceedings brought by the Department of Justice and the Federal Trade Commission. See Nezv Antitrust Policy Developing, Business Week, Aug. 1, 1953, p. 62; Address Of Chairman Hozorey, FTC Clip Sheet, June 15, 22, 1953; Oppenhein On Antitrust Grontp, id., July 16, 1953.

And there is already precedent that refusal to admit such evidence in a $\$ 7$ procecding constitutes reversable error. Transamerica Corp. v. Board of Governors of Feleril Reserve System, 206 F.2d 163, 169 (3d Cir. 1953).

36. "Workable competition" is the cardinal shibboleth of modern economic analysis. The concept was first introduced by Clark as a healthy antidote to the classical cconomists' disregard of the actualities of the market place. Clark, Tou'ards a Concept of Workable Competition, 30 AMr. Econ. Rev. 241 (1940). But the concept has never gone beyond the stage of theoretical validity; there has been as yet insufficient empirical analysis of actual industrial structures to give the concept detailed content. Thus ono of the leading "modern" economists has recently concluded that "there are as many definitions of 'effective' or 'workable' competition as there are 'effective' or 'workable' economists." Mason, The New Competition, 43 YaLe Rev. 37, 48 (1953). Sce also Wilcox, Discussion, 40 AM. Econ. Rev. Supp. 100 (1950); Bain, Workable Competition in Oligopoly: Theoretical Considerations and Some Empirical Evidence, 40 id. at 35, 37 (1950) ; Carlston, Vertical Integration and the Law in Vertical INTEGration IN MARIKETING, 148, 168-9 (Cole ed. 1952); Edwards, sispra note 14, at 59.

37. Stocking \& Watkins, Monopolx and Free Enterprise, cc. 4, 5 (1951); Bowman, Toward Less Monopoly, 101 U. of PA. L. Rev. 577, 631-41 (1953). The theory underlying this conclusion is analyzed in FellNer, CoMpetrtion Amono TuE Few (1949). Cf. Edwards, Maintaining Competition c. 4 (1949); Brems, Producr EquILIBRIUM UNDER Monopolistic CoMpetition (1951). This theory was onte of the reasons that led to the amendment of $\S 7$. SEN. ReP. No. 1775, 81st Cong., 2d Sess. (1950).

38. See Oppenheim, Federal Antitrust Legislation: Guideposts to a Revised National Antitrust Policy, 50 Mich. L. Rev. 1139, 1158-61, 1179-81, 1196-8 (1952); Handenk, A 
The Benrus case suggests that courts may use such a rebuttable presumption in Section 7 cases. Judge Hincks held that, unless a merger between Benrus and Hamilton would create a reasonable probability of harm to competition, the preliminary injunction would have to be denied. But this test was satisfied by a showing that the companies involved controlled a substantial share ${ }^{39}$ of the relevant line of commerce. ${ }^{40}$ However, such a showing did not create an irrebuttable presumption of illegality; it merely made out the prima facie case of violation of Section 7 necessary to support a preliminary injunction. ${ }^{41}$ The Second Circuit's affirmance emphasized that only a prims facie case of violation had been made out in the court below. 22 Thus buth

Study of the Construction and Exforcenent of the Ferier.ll Artitisest Lawis 89 (TNEC Monograph 38, 1940) ; Bowman, supra note 37, at 589-90, 638-41; Eain, sugra note 36, at 46-7; Stocking \& Wathins, Monopolx and Free ENtarrase 550-3, 564 (1951).

39. Judge Hincks held that the relevant line of commerce was the natiunal maricet in jeweled watches. On a unit basis he found that Hamilton sold 6 percent and Benrus 9 percent of the jeweled watches sold in the United States in 1950 . The figures were slightly lower for 1951 and 1952. It is significant that he held this to comprise a substantial share of the relevant market despite the fact that Elgin and Bulova cail sold more than Benrus and Hamilton combined. Hamilton Watch Co. v. Benrus Watch Co., 11t F. Sugp. 307, 310-11, 315 (D. Conn. 1953).

What constitutes a substantial share of the market should depend on the type of merger under consideration. The percentage relevant for vertical integration should ta the same held determinative for exclusive dealer contracts under $\S 3$ of the Act since vertical integration is at least as basic a restraint on competition as that imposed by such contracts. The percentage relevant for horizontal mergers should depend on the number of firms reasonably necessary for effective competition. A tentative amalysis suggests that whenever the firm resulting from the merger controls 10 percent of the relevant market, there should arise a rebuttable presumption of illegality. Sce Bain, sispra nute 36, at 46-7; Bowman, supra note 37, at 638-41. The figure relevant for conglomerate mergers is tied up with the general problem of the giant concern. See Euwanus, Mlar:icar:ano Conipetition 99-121, 130-2, 142-4 (1949).

40. This was the essence of Hamilton's argument in the Memorandum of Law which it submitted to Judge Hincks. He found himself "persuaded by the reasoning and citations appearing in plantiff's briefs." Hamilton Watch Co. v. Benrus Watch Co., 114 F. Supp. 307,315 (D. Conn. 1953).

41. Hamilton repeatedly argued that only a prima facie case of violation is nccessary to support a preliminary injunction and that the main purpose of a preliminary injunction is to maintain the status quo until a case can be decided on its merits. Plaintifi's Brief on the Preliminary Injunction, pp. 18-29, Hamilton Watch Co. v. Benrus Watch Co. 114 F. Supp. 307 (D. Conn. 1953) ; Plaintiff-Appellee's Brief on Appeal, pp. 14-15, 30, Hamilton Watch Co. v. Benrus Watch Co., 206 F.2d 738 (2d Cir. 1953). That Hamilton recognized that a rule of reason analysis would be admissible at the full hoaring is clcar from the following quote from its appeal brief: "The urgency of the need for preliminary relief precluded plaintiff from developing and presenting the full compctitic inglications of the Benrus acquisition. . . . These matters, of necessity, must await final haring. It w'as sufficient for the purpose of the proliminary relief sought that plaintifi establish a prima facie case of Section 7 violation. ..." Id. at 30 (emphasis supplied).

42. All that the record disclosed, declared the court of appeals, was that the lower "court, after a trial, may be required to conclude that Benrus was not innocent of a Section 7 violation." Hamilton Watch Co. v. Benrus Watch Co., 206 F.2d 738, 740 (2d 
courts left open the door to a rule of reason analysis by which the defendant could rebut the presumption of illegality raised by the evidence presented to the lower court.

The effectiveness of the antitrust laws depends ultimately upon the attitude of the courts in applying their broad generalities to specific fact situations. ${ }^{4 a}$ The original Section 7 was destroyed by courts which rarely refused to accept arguments of business expediency. ${ }^{44}$ The Benrus case suggests that the amended section will fare much better at the hands of the judiciary. It not only reaffirms potentiality of harm to competition as the standard of legality under Section 7 but suggests a restricted burden of proof on the plaintiff which will encourage vigorous enforcement of the section without prohibiting those intercorporate stockholdings and mergers which increase rather than decrease the effectiveness of competition.

Cir. 1953) (emphasis supplied). The court went out of its way to emphasize that Judge Hincks' conclusions of law as well as fact were only "interlocultory, tentative, provisional, ad interim, impermanent, mutable, not fixed or final or conlusive, characterized by its for-the-time-beingness." Id. at 742 .

43. Loevinger, Antitrust and the New Economics, 37 Mins. L. Rev. 505, 568 (1953).

44. Schwartz, supra note 31 , at 33 . 